\title{
Advances in the management of craniopharyngioma [version
}

\section{1; peer review: 3 approved]}

\author{
Lillie O'steen¹, Daniel J. Indelicato (iD2
}

${ }^{1}$ Department of Radiation Oncology, University of Florida, 2000 SW Archer Road, Gainesville, FL 32610, USA

${ }^{2}$ Department of Radiation Oncology, University of Florida, 2015 North Jefferson Street, Jacksonville, FL 32206, USA

V1 First published: 11 Oct 2018, 7(F1000 Faculty Rev):1632

https://doi.org/10.12688/f1000research.15834.1

Latest published: 11 Oct 2018, 7(F1000 Faculty Rev):1632

https://doi.org/10.12688/f1000research.15834.1

\section{Abstract}

Craniopharyngioma is a curable benign tumor, but owing to its intimate relationship to critical structures in the central brain-such as the optic apparatus, pituitary, hypothalamus, intracranial vasculature, brain stem, and temporal lobes-its management introduces the risk of long-term treatment morbidity. Today, the most common treatment approach is conservative subtotal resection followed by radiotherapy, and the goal is to limit long-term toxicity. Many recent advances in the treatment of craniopharyngioma are attributable to improved surgical techniques and radiotherapy technologies.

Keywords

Benign, pediatric, radiation therapy, surgery, outcomes, treatment side effects

\section{Open Peer Review}

Approval Status

1

2

3

\section{version 1}

11 Oct 2018

Faculty Reviews are review articles written by the prestigious Members of Faculty Opinions. The articles are commissioned and peer reviewed before publication to ensure that the final, published version is comprehensive and accessible. The reviewers who approved the final version are listed with their names and affiliations.

1. Yen-Ching Chang, University College London Hospitals NHS Foundation Trust, 1st Floor Central, 250 Euston Road, London, UK

2. Kristian Aquilina, Great Ormond Street Hospital for Children NHS Trust, London, UK

3. Hermann L Müller, Klinikum Oldenburg AöR, Medical Campus University Oldenburg, Oldenburg, Germany

Any comments on the article can be found at the end of the article. 
Corresponding author: Daniel J. Indelicato (dindelicato@floridaproton.org)

Author roles: O'steen L: Conceptualization, Data Curation, Writing - Original Draft Preparation, Writing - Review \& Editing; Indelicato DJ: Conceptualization, Project Administration, Supervision, Writing - Original Draft Preparation, Writing - Review \& Editing

Competing interests: No competing interests were disclosed.

Grant information: The author(s) declared that no grants were involved in supporting this work.

Copyright: ( 92018 O'steen L and Indelicato DJ. This is an open access article distributed under the terms of the Creative Commons Attribution License, which permits unrestricted use, distribution, and reproduction in any medium, provided the original work is properly cited.

How to cite this article: $O$ 'steen $L$ and Indelicato $D$ J. Advances in the management of craniopharyngioma [version 1; peer review: 3 approved] F1000Research 2018, 7(F1000 Faculty Rev):1632 https://doi.org/10.12688/f1000research.15834.1

First published: 11 Oct 2018, 7(F1000 Faculty Rev):1632 https://doi.org/10.12688/f1000research.15834.1 


\section{Introduction}

Craniopharyngioma is a benign tumor typically treated with both surgery and radiation, an approach that offers 5-year progression-free survival (PFS) rates exceeding 90\% ${ }^{1}$. Historically, these high tumor control rates have come at the cost of long-term side effects, such as endocrinopathy, hypothalamic dysfunction, visual field deficits, cerebrovascular sequelae, secondary malignancies, and neurocognitive decline, which significantly impact quality of life among this mostly pediatric population.

Whereas most benign tumors can be treated surgically, craniopharyngiomas present a surgical challenge because of their central location and close proximity to sensitive structures, such as the optic apparatus, pituitary, hypothalamus, circle of Willis, brain stem, and temporal lobes. Schoenfeld et al. retrospectively reviewed 122 patients whose craniopharyngioma was treated between 1980 and 2009 with gross total resection (GTR) or subtotal resection (STR) and radiotherapy ${ }^{2}$. GTR was associated with a significantly higher incidence of diabetes insipidus $(56.3 \%$ versus $13.3 \%, p<0.001)$ and panhypopituitarism (54.8\% versus $26.7 \%, p=0.014)$ and showed no improvement in PFS or overall survival ${ }^{2}$. In an analysis of 644 patients from the Surveillance, Epidemiology and End Results Program whose craniopharyngioma was treated between 2004 and 2008, Zacharia et al. examined factors such as younger age, smaller tumor size, and combined-modality therapy ${ }^{3}$. They found that STR and radiotherapy significantly improved survival. In addition, the 10-year local control rate was higher with STR plus radiation than with surgery alone (84\% versus $52 \%$; $p=0.006)^{3}$. STR alone has been associated with significantly inferior PFS compared with surgery and radiation ${ }^{2}$. Because aggressive surgery carries a higher risk of morbidity and the rates of progression with STR alone are unsatisfactory, the standard of care for most craniopharyngiomas involves conservative surgery with the goal of preserving vision and controlling hydrocephalus, followed by radiotherapy to optimize local control. Conservative surgical resection is of particular importance in cases with radiographic evidence of hypothalamic involvement, which is associated with decreased 10-year overall survival and an enduring impact on psychosocial quality of life ${ }^{4,5}$. Only a select subset of tumors, usually small and separate from the hypothalamus and optic pathway, may be cured with surgery alone.

The most recent advances in the treatment of craniopharyngioma have focused on minimizing treatment-related toxicity. These advances include endoscopic surgery and precision radiotherapy. Radiation therapy technology has improved dose conformality and provided decreased doses to adjacent critical structures with the goal of reducing long-term sequelae in this highly curable pediatric population.

\section{Endoscopic endonasal surgery}

Prior to the advent of endoscopy, only intrasellar, infradiaphragmatic lesions could be resected through an endonasal approach. With the advent of endoscopic endonasal surgery
(EES), suprasellar and select intraventricular tumors, which were accessible only using craniotomy, can now be resected using EES, often with improved clinical outcomes compared with transcranial resection. Karavitaki et al. reviewed 64 craniopharyngioma patients who underwent $\mathrm{EES}^{6}$. The GTR and near total resection rates were $37.5 \%$ and $34.4 \%$, respectively, similar to historical rates with transcranial resection ${ }^{6}$. There was no difference in extent of resection between intrasellar and suprasellar tumors. The rates of visual deterioration $(0 \%)$ and new endocrinopathies $(58.3 \%)$ were lower with EES compared with published results with transcranial resection ${ }^{7-9}$.

\section{Intensity-modulated photon radiation therapy}

The fundamental objective of radiotherapy is to deliver a therapeutic dose to the tumor target while limiting the dose to nearby normal structures. Intensity-modulated photon radiotherapy (IMRT) is a precise radiotherapy modality that tailors small beamlets of varying intensities to a complex target structure. Compared with three-dimensional conformal radiotherapy (3DCRT), IMRT offers improved dose conformality and reduced dose to adjacent normal structures. In a dosimetric study of 15 pediatric craniopharyngioma patients who underwent treatment planning for both 3DCRT and IMRT, IMRT reduced the mean dose to the cochlea from 18.2 to $13.3 \mathrm{~Gy}(p<0.001)$, temporal lobes from 14.3 to $7.9 \mathrm{~Gy}(p<0.001)$, and hippocampus from 26.8 to $17.6 \mathrm{~Gy}(p<0.001)^{10}$.

\section{Proton therapy}

Protons from a cyclotron or synchrotron travel through tissue delivering small dose until reaching their maximum depth, where, depending on their energy, they deposit a narrow distribution of dose before stopping, producing the characteristic Bragg peak. Unlike in photon-based radiation, no "exit" dose is delivered beyond the target with proton therapy. A "spread-out" Bragg peak can be created by delivering protons across a range of energies. In a dosimetric study of 10 pediatric craniopharyngioma patients who underwent treatment planning using IMRT, three-dimensional conformal proton radiotherapy (3DCPT), and intensity-modulated proton therapy (IMPT), both 3DCPT and IMPT demonstrated a relative reduction in the integral dose to the brain stem, hippocampus, dentate gyrus, vascular structures, subventricular zone, infratentorial region, supratentorial region, and whole brain ${ }^{11}$. Such a dose reduction to these intimately located critical structures can help lessen the acute and late toxicities of radiotherapy. Investigators of a Childhood Cancer Survivor Study analyzing pediatric patients with a variety of tumors calculated a 2 - to 15 -fold reduction in the incidence of second malignancies when proton therapy replaces conventional photon radiotherapy ${ }^{12}$. Compared with photon therapy, proton therapy offers a better opportunity to preserve IQ scores in patients with craniopharyngioma ${ }^{13}$. In a review of 40 pediatric craniopharyngioma patients who received proton radiotherapy, the 5-year local control and overall survival rates were $100 \%{ }^{14}$. Table 1 reviews the published outcomes on patients with craniopharyngioma treated with proton therapy ${ }^{14-22}$. A comparison of photon stereotactic radiotherapy and 3DCPT plans is shown in Figure 1. 
Table 1. Outcomes following proton therapy for patients with craniopharyngioma.

\begin{tabular}{|c|c|c|c|c|c|c|}
\hline $\begin{array}{l}\text { Study; } \\
\text { number of } \\
\text { patients }\end{array}$ & $\begin{array}{l}\text { Median } \\
\text { follow- } \\
\text { up, years }\end{array}$ & Treatment modality & $\begin{array}{l}\text { Actuarial } \\
5 \text {-year local } \\
\text { control rate }\end{array}$ & $\begin{array}{l}\text { Acute toxicity, } \\
\text { number of } \\
\text { patients }\end{array}$ & $\begin{array}{l}\text { Late toxicity, number of } \\
\text { patients }\end{array}$ & $\begin{array}{l}\text { Mortality (absolute } \\
\text { number), number of } \\
\text { patients }\end{array}$ \\
\hline $\begin{array}{l}\text { Fitzek et al. }{ }^{15} \\
\text { (2006); } N=15\end{array}$ & 13.1 & $\begin{array}{l}\text { Surgery/biopsy + } \\
\text { proton-photon }\end{array}$ & $93 \%$ 5-year & $\begin{array}{l}\text { None, } 7 ; \\
\text { nausea, 1; } \\
\text { fatigue, 3; } \\
\text { headaches, } 4\end{array}$ & $\begin{array}{l}\text { Visual deficits, 2; } \\
\text { endocrinopathy, 15; } \\
\text { learning difficulty, } 1\end{array}$ & $\begin{array}{l}\text { PD, 2; vascular } \\
\text { complications, 1; } \\
\text { treatment related } \\
\text { hypothalamic } \\
\text { syndrome, } 1\end{array}$ \\
\hline $\begin{array}{l}\text { Luu et al. }{ }^{16} \\
(2006) ; \\
N=16\end{array}$ & 5 & $\begin{array}{l}\text { Surgery + proton or } \\
\text { proton alone (surgery } \\
\text { + RT, 4; recurrent } \\
\text { after surgery, 12; } \\
\text { re-resection + RT, 7; } \\
\text { RT, 4) }\end{array}$ & $\begin{array}{l}94 \%^{a} \\
\text { (recurrence at } \\
80 \text { months, 1) }\end{array}$ & NR & $\begin{array}{l}\text { Panhypopituitarism, } 1 \text {; } \\
\text { CVA, } 1 \text { with full recovery; } \\
\text { meningioma, } 1 \text { following } \\
\text { re-irradiation }\end{array}$ & $\begin{array}{l}3 \text { at } 12,52 \text {, and } \\
120 \text { months after } \\
\text { re-resection and RT } \\
\text { (PD, 1; sepsis, 1; } \\
\text { MCA infarct, 1) }\end{array}$ \\
\hline $\begin{array}{l}\text { Winkfield } \\
\text { et al. }{ }^{17}(2008) \\
N=24\end{array}$ & 3.7 & $\begin{array}{l}\text { Surgery/biopsy + } \\
\text { proton therapy }\end{array}$ & $100 \%$ & NR & NR & $\begin{array}{l}\text { Intracranial } \\
\text { hemorrhage at } 1 \text { year, } \\
1 \text { (in a child with } 3 \\
\text { previous surgeries } \\
\text { followed by RT) }\end{array}$ \\
\hline $\begin{array}{l}\text { Chang et al. }{ }^{18} \\
\text { (2009); } N=14\end{array}$ & 1.3 & $\begin{array}{l}\text { Surgery/biopsy + } \\
\text { proton therapy }\end{array}$ & $100 \%$ a & NR & $\begin{array}{l}\text { Vision, stable or improved; } \\
\text { endocrinopathy, } 11 \text { (of } 11 \\
\text { with results) }\end{array}$ & 0 \\
\hline $\begin{array}{l}\text { Alapetite } \\
\text { et al. }{ }^{19}(2012) \\
N=49\end{array}$ & 4.4 & $\begin{array}{l}\text { Surgery + proton- } \\
\text { photon, 10; surgery + } \\
\text { proton, } 39\end{array}$ & $90 \%{ }^{a}$ & NR & $\begin{array}{l}\text { Altered short-term memory, } \\
\text { social and emotional } \\
\text { functioning and significant } \\
\text { school difficulties in children } \\
\text { who had RT after several } \\
\text { surgeries. } \\
\text { Behavioral disorder rates } \\
\text { lower after STR + RT. }\end{array}$ & NR \\
\hline $\begin{array}{l}\text { Confer et al. }{ }^{20} \\
\text { (2012); } N=13\end{array}$ & 0.7 & $\begin{array}{l}\text { Surgery/biopsy + } \\
\text { proton }\end{array}$ & $85 \%^{a}$ & $\begin{array}{l}\text { Grade } 2 \\
\text { headache, } 1\end{array}$ & NR & 0 \\
\hline $\begin{array}{l}\text { Indelicato } \\
\text { et al. }{ }^{14}(2012) \\
N=40\end{array}$ & 0.7 & $\begin{array}{l}\text { Surgery/biopsy + } \\
\text { proton therapy }\end{array}$ & $100 \%^{a}$ & $\begin{array}{l}\text { Emesis, } 1 ; \\
\text { headache, } 1 ; \\
\text { presyncope, } 2 \text {; } \\
\text { nausea, } 9\end{array}$ & None to date & 0 \\
\hline $\begin{array}{l}\text { Bishop et al. }{ }^{21} \\
\text { (2014); } N=21\end{array}$ & 2.75 & $\begin{array}{l}\text { Surgery/biopsy + } \\
\text { proton, 15; proton } \\
\text { alone, } 4\end{array}$ & $92 \%$ & NR & $\begin{array}{l}\text { Vasculopathy, 2; } \\
\text { endocrinopathy, } 16\end{array}$ & $\begin{array}{l}\text { Secondary to } \\
\text { surgically induced } \\
\text { DI, } 1\end{array}$ \\
\hline $\begin{array}{l}\text { Merchant } \\
\text { et al. } .^{22}(2017) \\
\mathrm{N}=94\end{array}$ & 2.65 & $\begin{array}{l}\text { Surgery/biopsy + } \\
\text { proton therapy }\end{array}$ & $\begin{array}{l}97.8 \% \\
\text { (3-year) }\end{array}$ & NR & $\begin{array}{l}\text { Preservation of academic } \\
\text { achievement }\end{array}$ & NR \\
\hline
\end{tabular}

\section{Spot scanning and intensity-modulated proton therapy} Spot scanning provides better proximal and distal target conformality compared with passive-scatter proton therapy by covering the target with small mono-energetic pencil beams steered by magnets. Dosimetric studies have shown that IMPT decreases the dose to normal surrounding tissue compared with double-scatter proton therapy ${ }^{23}$, as shown in Figure 2. However, spot scanning is more sensitive to changes in the volume of cystic craniopharyngiomas during treatment, which could lead to underdosing at the margins. Furthermore, most spot-scanning systems do not allow aperture-based delivery, which means that the beam penumbra may be less conformal at the lateral target.

\section{Reducing radiation target margins}

In radiation planning for all modalities, target volumes are delineated by using computed tomography simulation images fused to T1- and T2-weighted post-contrast thin-sliced (1 to $1.5 \mathrm{~mm}$ slice thickness) magnetic resonance imaging (MRI). The gross tumor volume (GTV) has historically been expanded by a margin of $10 \mathrm{~mm}$ to create the clinical target volume (CTV). However, in a prospective analysis of 88 children who received 


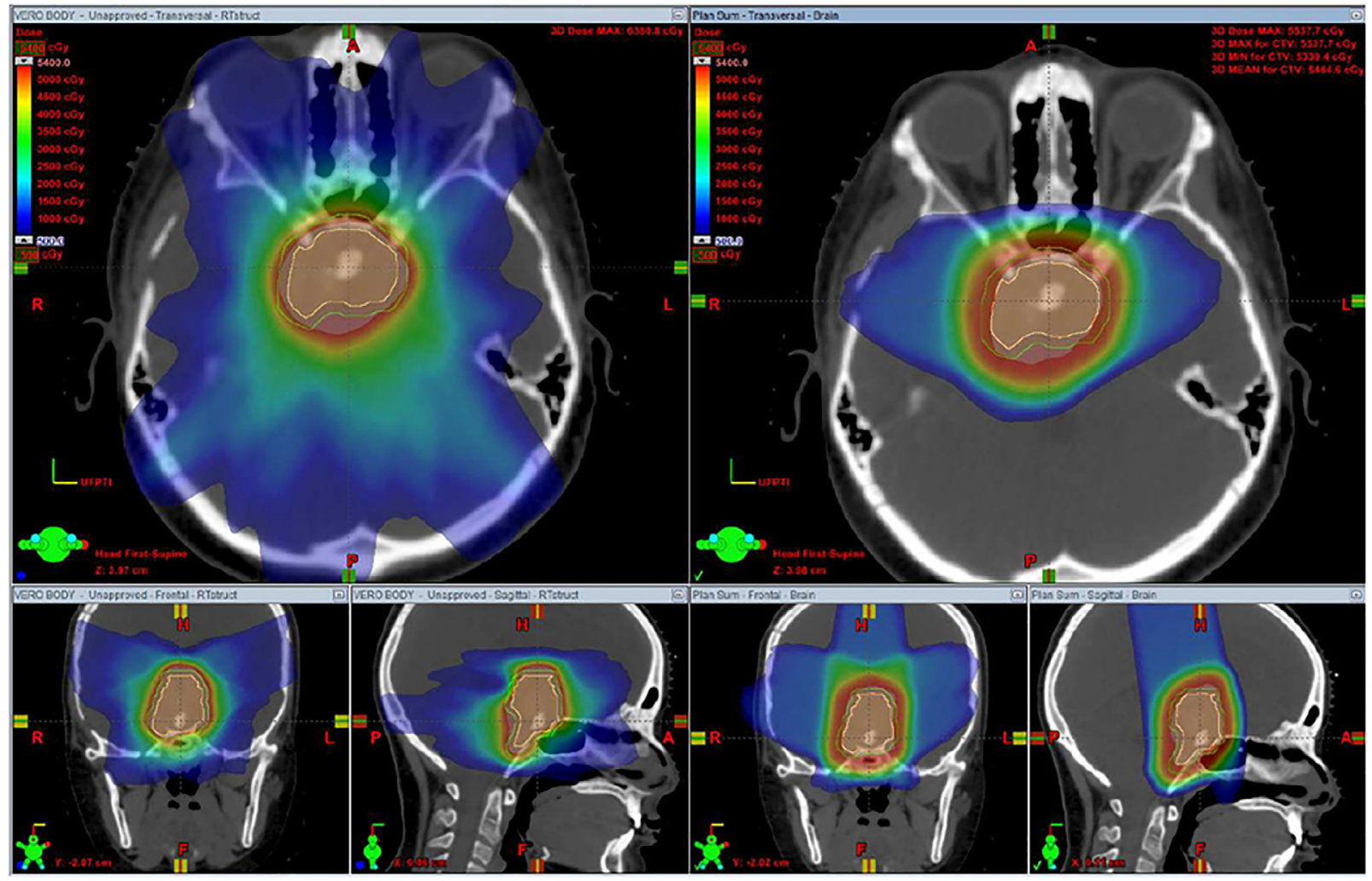

Figure 1. Dosimetric comparison of stereotactic radiotherapy with three-dimensional conformal proton therapy. Stereotactic radiotherapy (left) offers a sharp dose fall-off, but owing to the seven-beam arrangement with both entry and exit dose, a low dose is deposited diffusely in the region of the normal brain surrounding the central tumor. Three-dimensional conformal proton therapy (right) offers a sharp dose fall-off and, with a three-beam arrangement with no exit dose, offers less dose deposition in the normal brain tissue. The proton plan offers better sparing of the supratentorial brain and orbits. The figures are original images taken in our clinic for this publication.

radiotherapy between 1998 and 2009, a $5 \mathrm{~mm}$ and a $10 \mathrm{~mm}$ expansion for the CTV provided comparable $\mathrm{PFS}^{1}$. A recent phase II protocol (RT2CR, NCT01419067) at the University of Florida in conjunction with St Jude Children's Research Hospital prospectively evaluated a $5 \mathrm{~mm}$ CTV margin using proton therapy. Early results are promising in terms of both disease control and reduced toxicity ${ }^{22,24}$.

\section{Adaptive planning}

Improved conformality with the most recent technological advances in radiation therapy delivery increases the susceptibility of the proton dose distribution to the effects of dynamic cyst changes that occur throughout the 6 weeks of treatment. The GTV, by virtue of cyst reduction or enlargement, has been observed to change on average by $28.5 \%$ (range of $-20.7 \%$ to $82 \%$ ) during treatment when weekly MRIs are obtained ${ }^{10}$. Weekly MRIs during radiotherapy are used to identify these changes, and adaptive planning is necessary when changes in tumor volume may impact target coverage, as shown in Figure 3.

\section{Summary}

Craniopharyngioma is a curable benign tumor treated primarily by conservative resection and radiotherapy. Reducing the late toxicities of radiotherapy remains of pivotal importance in treating craniopharyngioma. Recent technological advances in radiotherapy offer the promise of reducing side effects while maintaining high cure rates. 


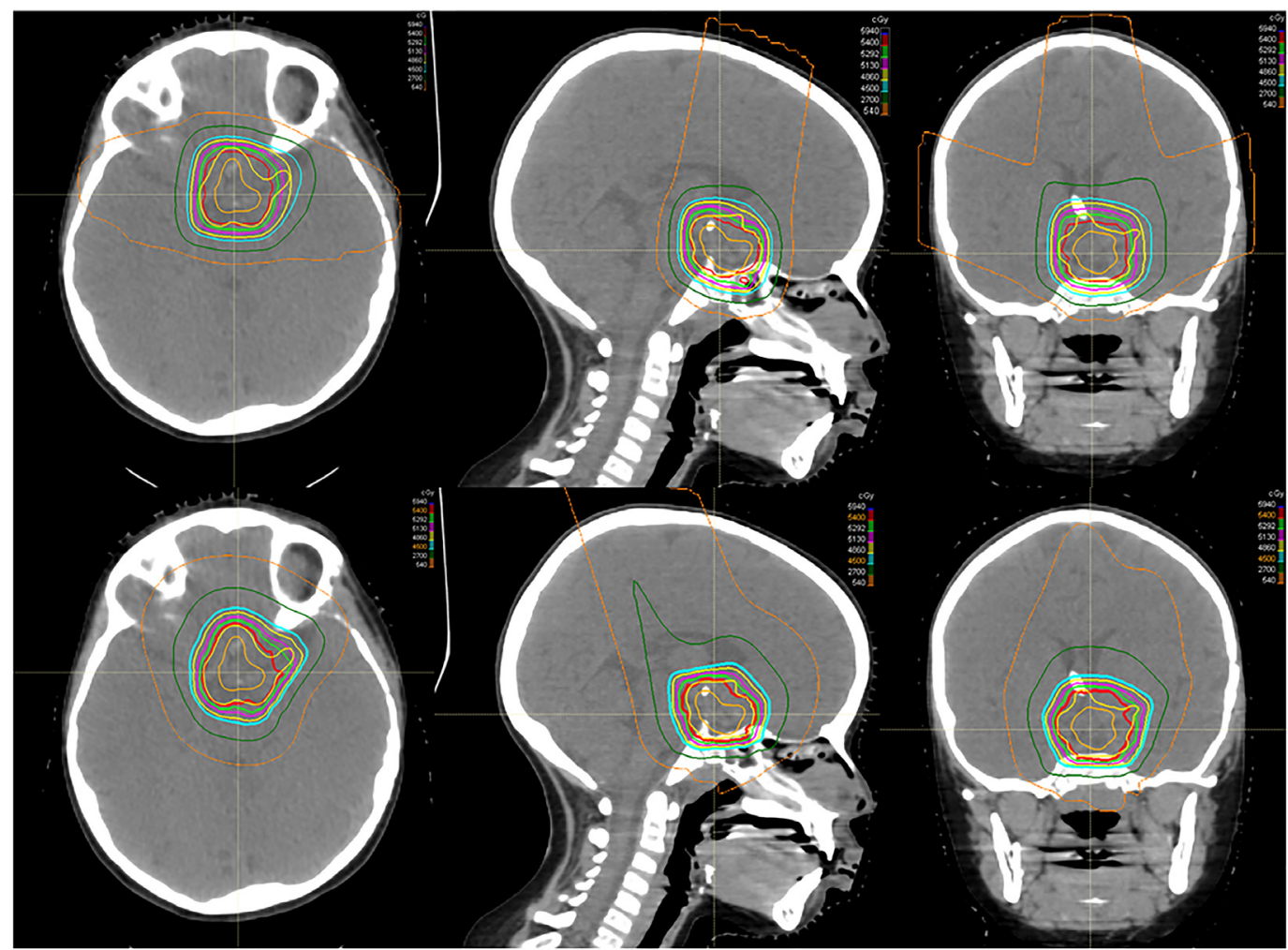

Figure 2. Dosimetric comparison of passive-scatter proton therapy and pencil-beam scanning. An example of the dose distribution for passive-scatter proton therapy (top) and pencil-beam scanning (bottom) in a patient with craniopharyngioma demonstrates comparable and acceptable target coverage in both plans. In this example, however, the pencil-beam modulation is used to create a more homogenous dose plan. The maximum doses to the optic chiasm are 55.6 Gy for the passive-scatter plan and 54.6 Gy for the pencil-beam scanning plan. The figures are original images taken in our clinic for this publication.

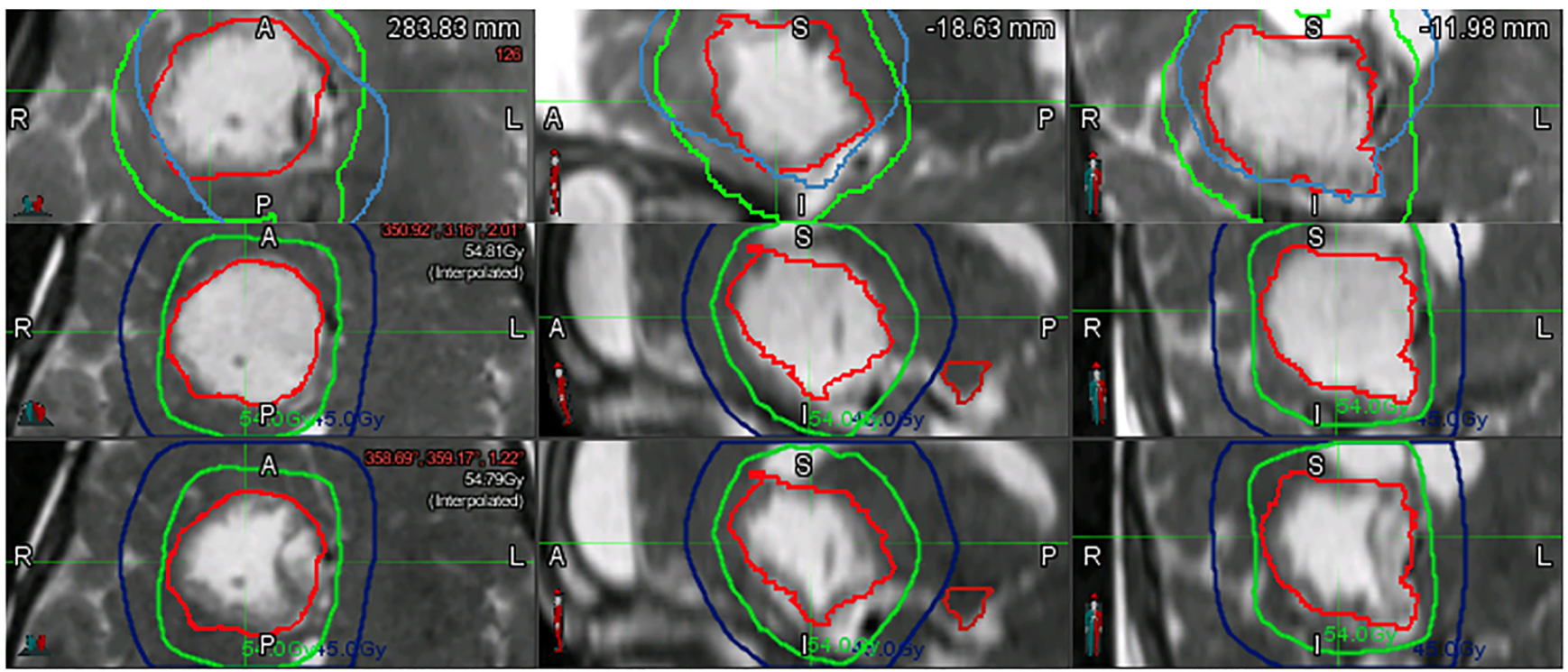

Figure 3. Dynamic cyst changes. Pictured are the T2-weighted magnetic resonance images (MRIs) in an axial, sagittal, and coronal presentation (left to right) taken weekly during radiotherapy for craniopharyngioma. The most superior MRI was obtained for radiation planning purposes, and the red line represents the contoured gross tumor volume. The images in the second row were obtained during the first week of radiation treatment and demonstrate cyst growth. The most inferior images were obtained during the second week of radiation treatment after the cyst had been drained via the Ommaya reservoir. The figures are original images taken in our clinic for this publication. 


\section{Abbreviations}

3DCPT, three-dimensional conformal proton therapy; 3DCRT, three-dimensional conformation radiation therapy; CTV, clinical tumor volume; EES, endonasal surgery; GTV, gross tumor volume; IMPT, intensity-modulated proton therapy; IMRT, intensity-modulated radiation therapy; MRI, magnetic resonance imaging; PFS, progression-free survival; STR, subtotal resection
Grant information

The author(s) declared that no grants were involved in supporting this work.

Acknowledgments

The authors thank Jessica Kirwan for editing and preparing the manuscript for submission.
1. $\mathrm{F}$ Merchant $\mathrm{TE}$, Kun $\mathrm{LE}$, $\mathrm{Hua} \mathrm{CH}$, et al: Disease control after reduced volume conformal and intensity modulated radiation therapy for childhood craniopharyngioma. Int J Radiat Oncol Biol Phys. 2013; 85(4): e187-92. PubMed Abstract | Publisher Full Text | Free Full Text | F1000 Recommendation

2. F Schoenfeld A, Pekmezci M, Barnes MJ, et al:: The superiority of conservative resection and adjuvant radiation for craniopharyngiomas. $J$ Neurooncol. 2012; 108(1): 133-9.

PubMed Abstract | Publisher Full Text | Free Full Text | F1000 Recommendation

3. F Zacharia BE, Bruce SS, Goldstein $\mathrm{H}$, et al:: Incidence, treatment and surviva of patients with craniopharyngioma in the surveillance, epidemiology and end results program. Neuro Oncol. 2012; 14(8): 1070-8.

PubMed Abstract | Publisher Full Text | Free Full Text | F1000 Recommendation

4. F Sterkenburg AS, Hoffmann A, Gebhardt U, et al:: Survival, hypothalamic obesity, and neuropsychological/psychosocial status after childhood-onset craniopharyngioma: newly reported long-term outcomes. Neuro Oncol. 2015; 17(7): 1029-38.

PubMed Abstract | Publisher Full Text | Free Full Text | F1000 Recommendation

5. $\quad \mathrm{F}$ Müller $\mathrm{HL}$ : Craniopharyngioma: long-term consequences of a chronic disease. Expert Rev Neurother. 2015; 15(11): 1241-4. PubMed Abstract | Publisher Full Text | F1000 Recommendation

6. Karavitaki N, Cudlip S, Adams CB, et al.: Craniopharyngiomas. Endocr Rev. 2006 27(4): 371-97.

PubMed Abstract | Publisher Full Text

7. $\quad F$ Koutourousiou M, Gardner PA, Fernandez-Miranda JC, et al:: Endoscopic endonasal surgery for craniopharyngiomas: surgical outcome in 64 patients. J Neurosurg. 2013; 119(5): 1194-207.

PubMed Abstract | F1000 Recommendation

8. Chakrabarti I, Amar AP, Couldwell W, et al.: Long-term neurological, visual, and endocrine outcomes following transnasal resection of craniopharyngioma. J Neurosurg. 2005; 102(4): 650-7. PubMed Abstract | Publisher Full Text

9. Fernandez-Miranda JC, Gardner PA, Snyderman $\mathrm{CH}$, et al.: Craniopharyngioma: a pathologic, clinical, and surgical review. Head Neck. 2012; 34(7): 1036-44. PubMed Abstract | Publisher Full Text

10. F Beltran C, Naik M, Merchant TE: Dosimetric effect of target expansion and setup uncertainty during radiation therapy in pediatric craniopharyngioma. Radiother Oncol. 2010; 97(3): 399-403. PubMed Abstract | Publisher Full Text | F1000 Recommendation

11. F Boehling NS, Grosshans DR, Bluett JB, et al.: Dosimetric comparison of three-dimensional conformal proton radiotherapy, intensity-modulated proton therapy, and intensity-modulated radiotherapy for treatment of pediatric craniopharyngiomas. Int J Radiat Oncol Biol Phys. 2012; 82(2): 643-52. PubMed Abstract | Publisher Full Text | F1000 Recommendation

12. F Friedman DL, Whitton J, Leisenring W, et al.: Subsequent neoplasms in 5year survivors of childhood cancer: the Childhood Cancer Survivor Study. J Natl Cancer Inst. 2010; 102(14): 1083-95.

PubMed Abstract | Publisher Full Text | Free Full Text | F1000 Recommendation
13. Merchant TE, Hua $\mathrm{CH}$, Shukla $\mathrm{H}$, et al:: Proton versus photon radiotherapy for common pediatric brain tumors: comparison of models of dose characteristics and their relationship to cognitive function. Pediatr Blood Cancer. 2008; 51(1): $110-7$.

PubMed Abstract | Publisher Full Text

14. Indelicato DJ, Rotondo R, Flampouri S, et al:: Proton Therapy for Craniopharyngioma: Early Clinical Outcomes. Int J Radiat Oncol Biol Phys. 2012; 84(3): S634. Publisher Full Text

15. Fitzek MM, Linggood RM, Adams J, et al.: Combined proton and photon irradiation for craniopharyngioma: Long-term results of the early cohort of patients treated at Harvard Cyclotron Laboratory and Massachusetts General Hospital. Int J Radiat Oncol Biol Phys. 2006; 64(5): 1348-54. PubMed Abstract | Publisher Full Text

16. Luu QT, Loredo LN, Archambeau JO, et al:: Fractionated proton radiation treatment for pediatric craniopharyngioma: preliminary report. Cancer J. 2006; 12(2): 155-9. PubMed Abstract

17. Winkfield KM, Linsenmeier C, Yeap BY, et al.: Proton Radiotherapy for Childhood Craniopharyngioma: Initial Clinical Outcomes. Int J Radiat Oncol Biol Phys. 2008; 72(1): S496. Publisher Full Text

18. Chang AL, Fitzek MM, Kruter LE, et al:: Outcomes of Pediatric Craniopharyngioma Treated with Proton Radiation Therapy. Int J Radiat Oncol Biol Phys. 2009; 75(3): S513. Publisher Full Text

19. Alapetite C, Puget S, Ruffier A, et al:: Proton therapy for craniopharyngioma in children: Update of the Orsay Proton Center experience. Neuro Oncol. 2012; 14 i22-i5: CR-09.

20. Confer ME, McNall-Knapp R, Krishnan S, et al:: Proton Radiation Therapy for Pediatric Craniopharyngiomas: Initial Results. Int J Radiat Oncol Biol Phys. 2012; 84(3): S635.

Publisher Full Text

21. Bishop AJ, Greenfield B, Mahajan A, et al.: Proton beam therapy versus conformal photon radiation therapy for childhood craniopharyngioma: multiinstitutional analysis of outcomes, cyst dynamics, and toxicity. Int J Radiat Oncol Biol Phys. 2014; 90(2): 354-61.

PubMed Abstract | Publisher Full Text | Free Full Text

22. Merchant TE, Hua CH, Sabin ND, et al:: Progression-Free Survival after Proton Therapy for Childhood Craniopharyngioma: Early Results From a Prospective Trial. Int J Radiat Oncol Biol Phys. 2017; 99(2): S59. Publisher Full Text

23. Yeung D, McKenzie C, Indelicato DJ: A dosimetric comparison of intensitymodulated proton therapy optimization techniques for pediatric craniopharyngiomas: a clinical case study. Pediatr Blood Cancer. 2014; 61(1): 89-94.

PubMed Abstract | Publisher Full Text

24. Merchant $\mathrm{T}$, Indelicato $\mathrm{D}$, Hua $\mathrm{CH}$, et al:: Comparison of academic achievemen scores after proton and photon therapy in children and young adults with craniopharyngioma [abstract]. Ped Blood Cancer. 2017; 64: S3. 


\section{Open Peer Review}

\section{Current Peer Review Status:}

\section{Editorial Note on the Review Process}

Faculty Reviews are review articles written by the prestigious Members of Faculty Opinions. The articles are commissioned and peer reviewed before publication to ensure that the final, published version is comprehensive and accessible. The reviewers who approved the final version are listed with their names and affiliations.

\section{The reviewers who approved this article are:}

\section{Version 1}

\section{Hermann L Müller}

Department of Pediatrics and Pediatric Hematology and Oncology, Klinikum Oldenburg AöR, Medical Campus University Oldenburg, Oldenburg, Germany

Competing Interests: No competing interests were disclosed.

\section{Kristian Aquilina}

Department of Neurosurgery, Great Ormond Street Hospital for Children NHS Trust, London, UK

Competing Interests: No competing interests were disclosed.

\section{Yen-Ching Chang}

Cancer Services, University College London Hospitals NHS Foundation Trust, 1st Floor Central, 250

Euston Road, London, NW1 2PG, UK

Competing Interests: No competing interests were disclosed.

The benefits of publishing with F1000Research:

- Your article is published within days, with no editorial bias

- You can publish traditional articles, null/negative results, case reports, data notes and more

- The peer review process is transparent and collaborative

- Your article is indexed in PubMed after passing peer review

- Dedicated customer support at every stage

For pre-submission enquiries, contact research@f1000.com 